\title{
CONCEPT OF “HIDDEN ASSETS" AND METHODOLOGICAL BASES FOR THEIR ASSESSMENT
}

\author{
Borys Burkynskyi ${ }^{1}$, Valeriy Goryachuk ${ }^{2}$, Julia Nazarenko ${ }^{3}$
}

\begin{abstract}
To assess the prospects of an enterprise and plan its activities, it is very important to know what assets it has, including hidden assets. Today, there is no single understanding of this concept. Some researchers attribute this to an underestimation of the company's assets, others - to a lack of accounting for assets, or to insufficient use of assets. This is the result of applying various methodological approaches and insufficient research of this concept. On the ground of a methodological approach based on the identification of generic concepts and essential features, a generalized definition of the concept of "hidden assets" is proposed. These are assets, value of which on the company's balance sheet is undervalued compared to their real value, or which are not reflected in the balance sheet, or which are underutilized and which are real assets, and which are capable to provide a competitive advantage or economic benefit. This definition of the concept of "hidden assets" allows to combine different existing points of view on this concept and to look at the capital of an enterprise in a broader context. The difference between the concepts of "hidden assets" and "accounted assets" from the point of view of law is considered separately. Assets that are recorded in the balance sheet belong to the enterprise based on ownership rights. As for hidden assets, as a rule, the enterprise in relation to them has the right to use only. Firstly, this applies to the leased fixed assets, human capital (use of time, knowledge and skills of specialists). In other words, the right to use is of crucial importance. In this case, the assets of the enterprise are considered as a set of rights to receive economic benefits. With such a broad view, the components of the hidden capital of an enterprise can be identified. Analysis of existing methodological approaches to the assessment of hidden assets has shown that they have significant methodological shortcomings and difficulties in applying and collecting the necessary initial data. Methodological bases for estimation of hidden assets are proposed based on the defined concept of "public value of an enterprise" as the sum of all assets used by an enterprise to create gross value added. Calculations have shown that the average share of hidden assets of Ukrainian enterprises in the period from 2012 to 2018 in the total volume of all assets is $33.7 \%$, and by type of economic activity from $14.3 \%$ in construction to $70.1 \%$ in agriculture. Hidden assets are the missing link in determining the level of capitalization of an enterprise. All other things being equal, the difference in the level of economic development of enterprises can be explained by differences in the volume and structure of their hidden assets. Hidden assets can be the key to creation of an enterprise's development strategy.
\end{abstract}

Key words: enterprise, Ukraine, types of activities, capital, social value, structure.

JEL Classification: D24, M11

\section{Introduction}

The dominant feature of enterprise development is capital. Traditionally, it is understood as assets that are accounted for in the balance sheet of an enterprise and belong to it based on ownership rights. However, the concept of enterprise capital is a broader concept and is not limited to the right of ownership. The right to use assets is important. This allows us to consider hidden assets as a component of the enterprise's capital, which are the missing link when determining the level of capitalization of the enterprise. All other things being equal, the difference in the level of economic development of enterprises can be explained by differences in the volume and structure of their hidden

\footnotetext{
Corresponding author:

${ }^{1}$ Institute of Market Problems and Economic\&Ecological Research of the National Academy of Sciences of Ukraine, Ukraine.

E-mail: burkinskij@nas.gov.ua

ORCID: https://orcid.org/0000-0001-9303-0898

${ }^{2}$ Institute of Market Problems and Economic\&Ecological Research of the National Academy of Sciences of Ukraine, Ukraine. E-mail: valeriygoryachuk@gmail.com

ORCID: https://orcid.org/0000-0001-7083-0863

${ }^{3}$ Institute of Market Problems and Economic\&Ecological Research of the National Academy of Sciences of Ukraine, Ukraine.

E-mail: ju.lia.uniti@gmail.com

ORCID: https://orcid.org/0000-0001-9049-1218
} 
assets. Identifying hidden assets and evaluating them is important when forming an enterprise development strategy.

The economic development of a country depends on the level of capitalization of business entities. The definition of the capital of an enterprise and its structure given in the Provisions (standards) of accounting in Ukraine does not meet the modern understanding and needs of the development of enterprises and the country's economy. In this context, it is relevant to develop a broad understanding of the company's capital in terms of "hidden assets" and their valuation.

\section{Literature review}

\subsection{Semantic analysis of the concept of "hidden assets"}

Capital is the main source of economic development of both society and individual enterprises. As Fisher (1927) noted it, capital is any asset that provides income (value added). According to accounting, the capital of an enterprise is its assets formed by investing its own and borrowed capital. Skillful use of assets ensures that the enterprise receives benefits now and in the future, and the relevant legislative and regulatory framework ensures ownership of its assets. At the same time, the idea of the company's capital and its assessment based on its balance sheet has significant disadvantages:

- firstly, the discrepancy between the value of assets according to accounting and their real value. As a rule, there is an underestimation of the cost, which is due to inflation processes and other factors;

- secondly, there are assets that are controlled by the enterprise and used for profit, but are not accounted for in the balance sheet of the enterprise.

To assess the prospects of an enterprise and plan its activities, it is very important to know what assets it has, including hidden assets. Today, there is no single understanding of this concept. Some researchers attribute this to an underestimation of the company's assets, others - to a lack of accounting for assets, or to insufficient use of assets (Chukhrai, 2012; INSIDERpro, 2017; Lopatnikov, 2003; Moiaosvita, 2017; Shchepotev, 2011; Viazemskaia, n.d.). This is the result of applying various methodological approaches and insufficient research of this concept. Our analysis has shown that hidden assets are the assets that are:

- not included in the balance sheet, but give the company some benefits;

- written off (amortized);

- not the property of the company, but are controlled and used by it (for example, leased fixed assets);

- the information; that are the relationships with partners and clients;

- a human capital;
- a customer capital (relations with customers and suppliers);

- a company image, organizational structure of the enterprise, databases, administrative systems, research and development.

Each of the above-mentioned definitions of the concept of "hidden assets" enriches the understanding of the essence of this concept, but none of them provides an exhaustive description of it. That is, we can talk about the relevance of the task of formulation of a generalized definition of the concept of "hidden assets", which would cover all the variety of points of view on this phenomenon. To solve this problem, a methodological approach was used, which provides for the following sequence of actions (Burkynskyi \& Horiachuk, 2014):

- structuring of existing definitions of the concept under study, namely, highlighting in each of them the generic concept and essential features;

- formation of generalized generic concepts and essential features;

- synthesis of a generalized definition of a concept.

As a result, a generalized definition of the concept of "hidden assets" is proposed. These are assets whose value on the company's balance sheet is undervalued compared to their real value, or which are not reflected in the balance sheet, or which are underutilized and which are real assets, and which are capable to provide a competitive advantage or economic benefit.

This definition of the concept of "hidden assets" allows to combine different existing points of view on this concept and to look at the capital of an enterprise in a broader context.

Separately, we should consider the difference between the concepts of "hidden assets" and "accounted assets" from the point of view of law. Assets that are recorded in the balance sheet belong to the enterprise based on ownership rights. The latter is considered in the legislation as a triad of the owner's rights - the right to own, the right to use and the right to dispose of a thing. As for hidden assets, as a rule, the enterprise in relation to them has only the right to use. Firstly, this applies to the leased fixed assets, human capital (use of time, knowledge and skills of specialists). In other words, the right to use is of crucial importance. In this case, the assets of the enterprise are considered as a set of rights to receive economic benefits. With such a broad view, the components of the hidden capital of an enterprise can be identified.

Hidden assets are the missing link in determining the level of capitalization of an enterprise. All other things being equal, the difference in the level of economic development of enterprises can be explained by differences in the volume and structure of their hidden capital. Hidden assets can be the key to creation of an enterprise's development strategy. 


\subsection{Analysis of methodological approaches to the assessment of hidden assets}

To assess hidden assets, experts use a number of methods, which are divided into four groups (Golovchanskaia \& Stelchenia, 2015; Li, et al, 2016; Sveiby, 2010):

- methods of direct valuation of hidden assets, the essence of which is to evaluate these assets directly;

- market capitalization methods that are based on comparing the market capitalization of an enterprise and the value of its assets;

- methods for estimating the return on use of assets, which are based on comparison of the income of an enterprise and the value of its assets;

- scoring methods. They provide for the identification of various components of hidden assets, which will be presented in the form of a system of indicators and which are evaluated in points. These methods do not involve obtaining monetary estimates of hidden assets.

Let us take a closer look at these groups of methods for evaluating hidden assets.

Methods for direct valuation of hidden assets. These methods first determine the components of hidden assets. Then the cost of each of them is estimated. The third optional step is to determine an integral (total) estimate of the value of hidden assets.

The disadvantages of this group of methods include: - imperfect methods for evaluating individual components of hidden assets. This is especially true for intellectual capital, due to its intangible essence, the uniqueness of its individual elements;

- failure to take into account the synergistic effect of the interaction of various components of hidden assets.

Market capitalization methods. They are based on a comparison of the market value of an enterprise and its assets. There are several approaches to calculation of the value of hidden assets:

- as the difference between the market value of an enterprise and the cost of restoring its assets (Reproduction Cost);

- as the difference between the market value of an enterprise and the cost of replacing its assets (Replacement Cost);

- as the difference between the market value of an enterprise and the book value of its assets (Book Value).

The first two approaches in methodological terms should give a more adequate assessment of hidden assets, because they use an assessment of the value of the enterprise and its assets in actual (current) prices. As part of the third approach to calculation of the value of hidden assets, it is defined as the difference between the market value of an enterprise and the book value of its assets. The latter may differ significantly from the real value if the indexation and revaluation of assets has not been performed. However, given the difficulties in estimating the cost of restoring or replacing assets, their book value is often used in practice, especially when it comes to the evaluation of the enterprises in the industry or the entire market.

The disadvantage of the market capitalization method is the possibility of obtaining negative values, which is due to the algorithm for the calculation of the hidden assets as a balance and the use of various methodological approaches to assessing the market value of an enterprise and the value of its assets.

The Tobin's $Q$ ratio is widely recognized in the valuation of hidden assets, namely such a component as intellectual capital (Hayes, 2020; Sokolianskii \& Sysoeva 2015).

$$
\mathrm{Q}=\mathrm{P} / \mathrm{A} \text {, }
$$

where: $\mathrm{P}$ is a market value of an enterprise, which is usually defined as the value of its shares; A is a reproduction cost of the enterprise's assets, that is equal to the sum of the costs required to restore all its assets at current prices.

Many experts believe that when the Tobin $Q$ ratio is greater than one, it is due to the presence of some assets that are not taken into account in the balance sheet of the enterprise; first, we are talking about intellectual capital. As a justification, they use the results of calculations of the Tobin Q ratio for IT companies in comparison with oil and gas and mining companies, whose activities are based on large amounts of physical capital (Golovchanskaia \& Stelchenia, 2015; Komarova \& Krupina 2017).

T. Piketty (2014) performed calculations of the Tobin $Q$ ratio for the developed countries (the USA, Great Britain, France, Germany, Japan) for the period from 1970 to 2010, which showed that the absolute majority of companies in developed countries have the Tobin $\mathrm{Q}$ ratio value of less than one. The average Tobin $Q$ ratio value in the period from 1970 to 2010 in the United States was about 0.80 .

The fact that most companies in developed countries have the Tobin $Q$ ratio value of less than one cannot indicate the absence or negative value of hidden assets, especially intellectual capital, because by its nature it and such a component as human capital cannot be negative. Accordingly, the difference between the market value of a company and the value of its assets or equity cannot be considered the value of hidden assets.

1. Methods for estimating the return on assets. These methods are based on comparison of the income of an enterprise and the value of its assets. The approach to the valuation of hidden assets, namely their main component - intellectual capital, based on the Value Added Intellectual Coefficient (VAIC) model, has been widely recognized. According to the experts, its advantage lies in the fact that calculations are simple and all the necessary information can be easily obtained in the financial statements of companies (Bryl \& Truskolask, 2015; Forte, et al., 2017; Javornik, et al., 
2012; Mohamed, 2017; Pulic, 2008; Smriti, et al., 2017; Stahle, et al., 2011; Svanadze \& Kowalewska, 2015).

Calculations of the VAIC coefficient are based on the following concepts:

- human capital (HC), which is interpreted as staff costs (salaries and accruals);

- structural capital (SC), which is interpreted as the difference between generated value added (VA) and human capital (HC), i.e. $\mathrm{SC}=\mathrm{VA}-\mathrm{HC}$;

- capital employed (CE), which is interpreted as the book value of the net asset, i.e. as equity.

Based on these definitions and assumptions, the VAIC coefficient is calculated as the sum of the following performance indicators:

- capital efficiency $(\mathrm{CEE})=\mathrm{VA} / \mathrm{CE}$;

- human capital efficiency $(\mathrm{HCE})=\mathrm{VA} / \mathrm{HC}$;

- structural capital efficiency $(\mathrm{SCE})=\mathrm{SC} / \mathrm{VA}$.

$$
\mathrm{VAIC}=\mathrm{CEE}+\mathrm{HCE}+\mathrm{SCE}
$$

The average values of the VAIC coefficient of Ukrainian enterprises by type of economic activity in the period from 2012 to 2018 are presented in Table 1, which shows that it has a value greater than 2.5 , which is according to classification of Pulic indicates very efficient business management (Pulic, 2008). However, this contradicts the current state of the economy and the processes of deindustrialization and dominance of raw materials industries in the country.

\section{Table 1}

Average values of the VAIC coefficient for Ukrainian enterprises as a whole and by type of activity in the period from 2012 to 2018

\begin{tabular}{|c|c|}
\hline & VAIC \\
\hline TOTAL & 4.17 \\
\hline Agriculture & 5.72 \\
\hline Industry & 4.13 \\
\hline Construction & 3.82 \\
\hline Trade & 5.69 \\
\hline Transport & 3.36 \\
\hline
\end{tabular}

Source: calculated on the basis of data from the statistical collection "Activities of business entities" for 2018

To explain this contradiction, we will consider the methodological basis of the VAIC coefficient model. It uses such concepts as "human capital", "structural capital" and "intellectual capital". However, their interpretation and understanding do not correspond to the generally accepted ones.

Firstly, in the model, human capital is interpreted as personnel costs (wages and accruals). However, this is not human capital, but a payment for its use. Just as the rent for the use of physical capital (fixed assets) is not physical capital. The same can be said about interest on deposits in banks, because this is a fee for the use of financial capital, and not it itself. In many scientific papers, personnel costs are used to estimate human capital based on a revenue-based approach by discounting them and then adding them up or capitalizing them (Koritckii, 2013). This assessment of human capital is several times or even higher than the cost of personnel.

Secondly, in the VAIC ratio model, structural capital (SC) is defined as the difference between value added (VA) and human capital (HC)

$$
\mathrm{SC}=\mathrm{VA}-\mathrm{HC} \text {. }
$$

If we take into account the definition of VA given in the model, namely

$$
\mathrm{VA}=\mathrm{HC}+\mathrm{P}+\mathrm{A} \text {, }
$$

where: $\mathrm{HC}$ is human capital: $\mathrm{P}$ is operating profit; $\mathrm{A}$ is amortization;

Then we get that

$\mathrm{SC}=\mathrm{P}+\mathrm{A}$.

However, structural capital cannot be calculated as the sum of operating profit and amortization, because the experts define it as software, organizational structures, ideas, trademarks, patents, license agreements, customer relations, etc. In addition, when operating profit is negative, the company's structural capital can also be negative, which contradicts its essence (Fijałkowska, 2014).

Thirdly, in the VAIC coefficient model, the sum of structural and human capital is defined as intellectual capital (IC) and as value added (VA). That is, intellectual capital is defined as gross value added

$$
\mathrm{IC}=\mathrm{VA} \text {. }
$$

However, this does not contradict the economic essence of value added, which is created by all types of capital used by the enterprise - physical, natural, intellectual, social, financial, etc. Therefore, value added cannot be considered as intellectual capital.

Thus, the VAIC coefficient model declares the use of the concept of intellectual capital, but in fact, it does not have this, and therefore it cannot be considered as a tool for evaluating intellectual capital

Scoring methods. These methods determine the various components of intellectual capital that will be represented in the system of indicators or in charts. The use of scoring methods does not provide for obtaining a monetary assessment of intellectual capital. The advantages of these methods are that they can create a more complete picture of the state of the enterprise than financial indicators, and that they can be easily applied at any level of the organization. They are measured closer to the event and therefore reporting can be obtained more accurately and faster than purely financial indicators. The disadvantages of these methods are that metrics are contextual and must be configured separately for each enterprise and each goal, which makes it very difficult to compare different enterprises. Scoring methods are relatively new and are not easily perceived by society and managers, who are used 
mainly to using financial indicators (Golovchanskaia \& Stelchenia, 2015; Mohamed, 2017; Sveiby, 2010).

Summing up the analysis of existing methods for evaluation of hidden assets and their main component - intellectual capital, it should be noted that they have significant methodological flaws and difficulties in applying and collecting the necessary initial data.

\section{Methods}

When making an investment, an investor sacrifices something less today for the sake of getting something more tomorrow. That is, it means that the investor invests in an enterprise and, accordingly, forms his or her asset expects not only to return the investment, but also to receive additional income (capital). That is, the cost (capitalization) of an enterprise based on the income approach should be greater than based on the investment (cost) approach. One of the main factors in this state of affairs is the presence of hidden assets.

As the basic provisions of the methodological base for assessing hidden assets, the following are proposed:

- capital is the value that creates added value;

- capital of an enterprise is a broader concept than its balance sheet assets. Capital of the enterprise, which ensures the creation of gross value added, is the assets that are accounted for in the balance sheet of the enterprise, and hidden assets, including human capital, leased physical assets (fixed assets, etc.), natural capital, social capital and other hidden assets (Figure 1);

- main result of the company's activity is gross value added, not profit;

- social value of an enterprise is the value of all assets that the enterprise uses to create gross value added. It is estimated based on the income approach, where income is gross value added (Figure 1).

Hidden assets will be calculated as the difference between the public value of the enterprise (the value of all types of capital involved) and the value of its balance sheet assets.

$$
\begin{aligned}
& \mathrm{HA}=\mathrm{PVE}-\mathrm{BSA} \\
& \mathrm{PVE}=\mathrm{GVA} / \mathrm{CR}
\end{aligned}
$$

where: PVE is public value of enterprise; BSA are balance sheet assets; GVA is gross value added that creates the enterprise; CR is capitalization rate.

It is also proposed to calculate the hidden asset ratio (RHA) according to the formula

$$
\mathrm{RHA}=\mathrm{PVE} / \mathrm{BSA}-1 \text {. }
$$

\section{Results and discussion}

The results of calculating the RHA show that in the period from 2012 to 2018 it fluctuated around the average value of 0.54 (Figure 2). This indicates the presence of hidden assets.

In agriculture and transport in the period from 2012 to 2018 , there was a tendency to reduce the RHA from 3.19 and 2.24 to 2.27 and 1.31, respectively. At the same time, in agriculture, a significant drop occurred in 2016 and it is associated with a sharp increase in accounts receivable and, accordingly, a significant increase in the value of assets. In transport, a significant drop in the RHA occurred in 2015 and is associated with a significant indexation of fixed assets and intangible assets and, accordingly, a significant increase in the value of assets (Figure 3).

The results of calculations of the RHA for industrial enterprises in the period from 2012 to 2018 indicate a tendency to increase it from 0.25 to 0.34 , but it is lower than in the whole country (average values of 0.21 and 0.54 , respectively). In trade, there is also a positive trend in terms of the RHA, but it is higher than in industry and in the country as a whole (average value of 0.55 ) (Figure 4).

In construction, in the period from 2012 to 2018, there was a tendency to increase the RHA, but at the same time, it should be noted that the average value of this coefficient was 0.22 , that is, almost at the same level with industry (Figure 5).

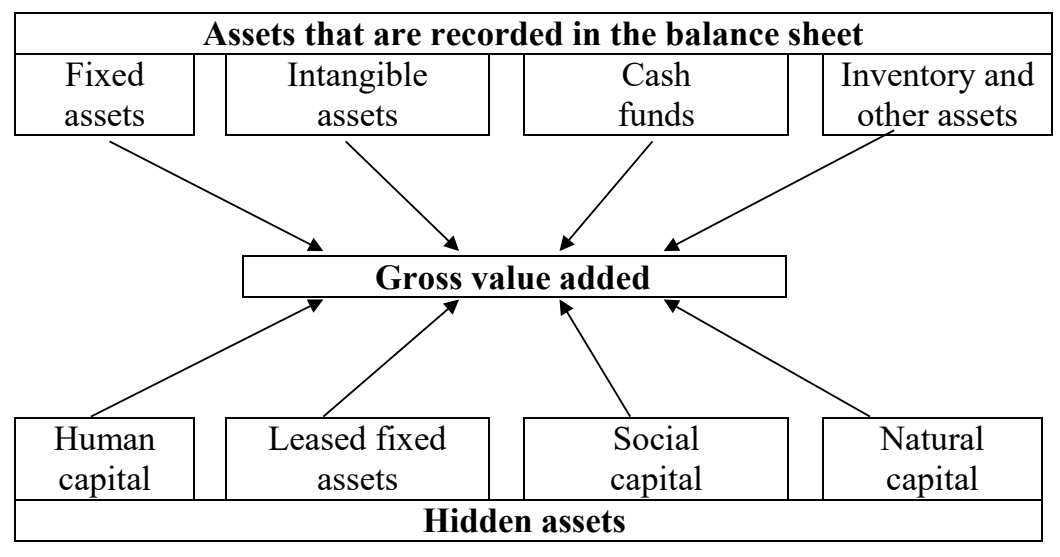

Figure 1. Types of assets (capital) that create gross value added 
Vol. 6, No. 5, 2020

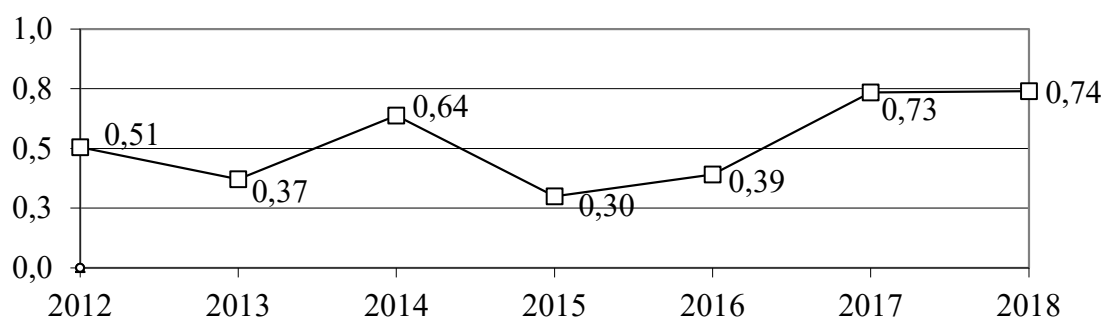

Figure 2. The RHA for Ukrainian enterprises in the period from 2012 to 2018

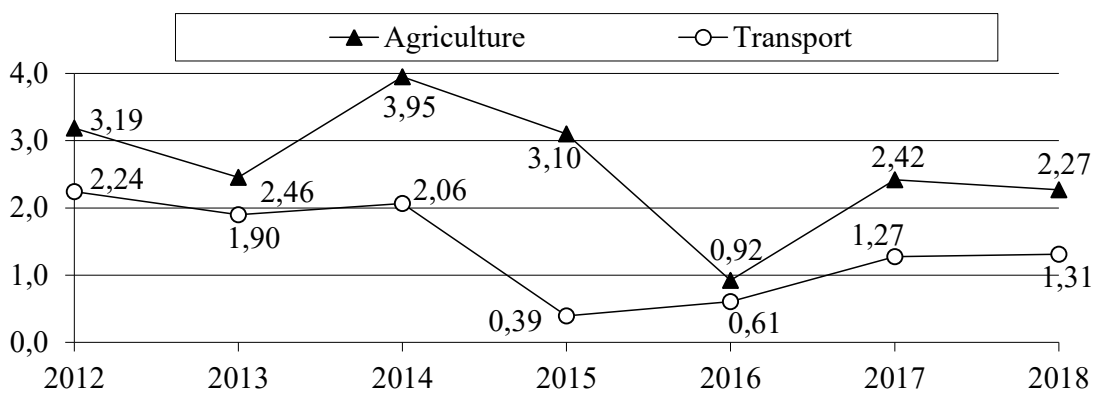

Figure 3. The RHA for agricultural and transport enterprises in the period from 2012 to 2018

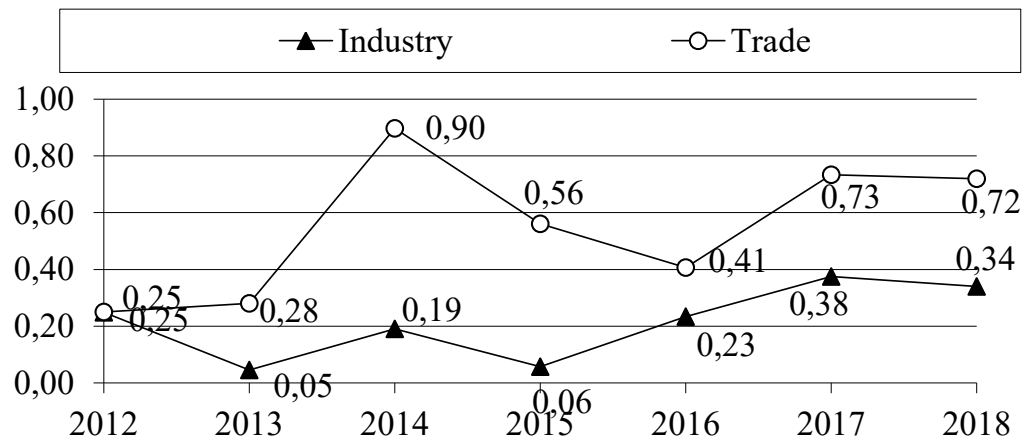

Figure 4. The RHA for industrial and trade enterprises in the period from 2012 to 2018

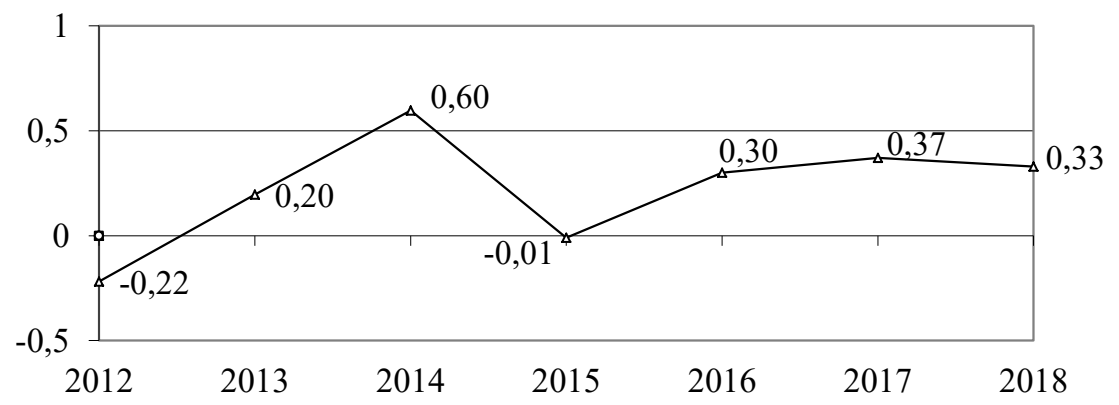

Figure 5. The RHA for construction enterprises in the period from 2012 to 2018

The value of hidden assets was calculated according to Formula 2. Calculations for the period from 2012 to 2018 show that the average share of hidden assets in the total capital of enterprises in the country is $32.2 \%$, the largest share in agriculture is more than $70 \%$, and the smallest share in construction is $12.5 \%$ (Table 2).
The fact that the highest share of hidden assets is in agriculture to a certain extent can be explained by the fact that unlike other types of activities, gross value added is created in addition to physical, human, social, financial capital, also natural capital in the form of land, also by the fact that agriculture of Ukraine in modern conditions has become one of the leading export industries. 
Table 2

Average share of hidden assets

in the total capital of enterprises

by type of activity in the period from 2012 to 2018

\begin{tabular}{|c|c|}
\hline & Share of hidden assets, $\%$ \\
\hline TOTAL & 33.7 \\
\hline Agriculture & 70.1 \\
\hline Industry & 16.8 \\
\hline Construction & 14.3 \\
\hline Trade & 34.0 \\
\hline Transport & 54.4 \\
\hline
\end{tabular}

Based on the assessment of hidden capital, we will proceed to the assessment of its components.

Human capital. There are various approaches to the assessment of human capital, and the approach based on the method of capitalization of personnel costs is widely recognized (Burkynskyi \& Horiachuk, 2014; Koritckii, 2013).

$$
\mathrm{HC}=\mathrm{S} / \mathrm{CR} \text {, }
$$

where: HC is human capital, $\mathrm{S}$ is Salary for accrual on it, $\mathrm{CR}$ is capitalization rate.

The capitalization rates used were the same as when calculating the public value of enterprises by type of activity. Calculations for the period from 2012 to 2018 show that the average share of human capital in the total capital of enterprises in the country is $26.9 \%$, the smallest - in trade and agriculture, respectively, $18.8 \%$ and $20.3 \%$, and the largest in transport $-36.6 \%$ (Table 3).

Table 3

Average share of human capital

in the total capital of enterprises

by type of activity in the period from 2012 to 2018

\begin{tabular}{|c|c|}
\hline & Share of human capital, \% \\
\hline TOTAL & 26.9 \\
\hline Agriculture & 20.3 \\
\hline Industry & 30.3 \\
\hline Construction & 30.6 \\
\hline Trade & 18.8 \\
\hline Transport & 36.6 \\
\hline
\end{tabular}

Leased fixed assets. According to the Provisions (standards) of accounting in Ukraine, leased fixed assets are accounted for in off-balance sheet account 01 "Leased non-current assets", their value is not taken into account in the total amount of assets of the enterprise. This allows you to avoid double accounting if we are not talking about one specific enterprise, but about all enterprises of a separate type of activity or all enterprises of the country, because leased fixed assets are accounted for on the balance sheet of the lessor's enterprise.

Natural capital. In Ukraine, minerals, agricultural land and other natural resources are mainly state property.
Therefore, they are not taken into account on the balance sheet of enterprises. That is, they are hidden assets that can be very significant for creating the gross value added of enterprises, for example, in the field of agriculture (land) or the extractive industry (minerals). The value of natural resources is determined according to their assessment in the relevant markets or with the involvement of experts (appraisers).

The assessment of the value of the agricultural land involved can be carried out based on rent for a 20year period. The value of the land used by agricultural enterprises is calculated based on the fact that the share is $80 \%$ of the total volume of agricultural land used.

The area of land used by agricultural enterprises in the period from 2012 to 2018 fluctuated slightly and averages 21.2 million ha, and the cost increased 3.2 times due to a significant increase in rent and reached 720.8 billion UAH.

Social capital. This type of capital will be understood as the capital of the internal organization of the enterprise and the capital of its external environment. The second component will be considered as an external institutional environment related to the state of the market, the effectiveness of public administration, corruption and other factors. Social capital can have a negative impact on the creation of gross value added and can be negative. Ronald Becker, who identifies human capital, structural capital and social capital in the structure of intellectual capital, points out this possibility. He focuses on the existence of negative human capital, negative structural capital, and negative social capital. He explains the paradoxical nature of this phenomenon by saying that not every element of intellectual capital contributes to making a profit. Ronald Becker writes, "The examples of negative intellectual capital in an organization have included a strong commitment to old methods that prevent your people from reaching their potential" (Lekarkina, 2017).

This provision at first glance raises the question of whether capital can be negative. In support of Ronald Becker's statements, it should be added that there are other factors that relate to the components of social capital and that can negatively affect the creation of added value and, accordingly, be considered as negative capital. In the conditions of Ukraine, these are inefficient government activities, unsatisfactory quality of the legislative and regulatory framework, low level of compliance with laws and regulations, and a huge scale of corruption that covers all levels of government and society.

Accordingly, we can talk about the possibility of negative values of social capital.

Based on the above-mentioned the assessment of social capital for an individual enterprise is proposed to be carried out as follows 


$$
\mathrm{SC}=\mathrm{HA}-\mathrm{HC}-\mathrm{LFA}-\mathrm{NC}
$$

where: SC is social capital of enterprise; HA are hidden assets of enterprise; $\mathrm{HC}$ is human capital of enterprise; LFA are leased fixed assets; NC is natural capital.

And for the type of activity or all enterprises in the country, taking into account the nature of accounting for the lease of fixed assets,

$$
\mathrm{SC}=\mathrm{HA}-\mathrm{HC}-\mathrm{NC}
$$

where: SC is social capital of enterprise; HA are hidden assets of enterprise; $\mathrm{HC}$ is human capital of enterprise; NC is natural capital.

Calculations of social capital in the total capital of enterprises by type of activity for the period from 2012 to 2018 are presented in Table 4. They show that the average share of social capital in the total capital of enterprises in the country is only $3.5 \%$, the largest in agriculture $-31.3 \%$, in transport and trade, respectively, $17.8 \%$ and $15.2 \%$, and the smallest in industry and construction, moreover it is negative $(-13.5 \%$ and -16.4$)$.

Table 4

Average share of social capital in the total capital of enterprises by type of activity in the period from 2012 to 2018

\begin{tabular}{|c|c|}
\hline & Share of social capital, \% \\
\hline TOTAL & 3.5 \\
\hline Agriculture & 31.3 \\
\hline Industry & -13.5 \\
\hline Construction & -16.4 \\
\hline Trade & 15.2 \\
\hline Transport & 17.8 \\
\hline
\end{tabular}

High values of the share of social capital in the case of agriculture can be explained, firstly, by the lack of a land market in Ukraine and, accordingly, an underestimation of the value of land, and secondly, by the significant export potential of the industry. In the case of transport - a favorable geographical location at the crossroads of trade routes and a significant potential for exporting services. The negative value of the social capital in industry can be explained by the process of deindustrialization, low technological level and corresponding outflow of skilled labor abroad, high loan rates and lack of working capital.

The structure of the total capital of Ukrainian enterprises by type of activity, taking into account the hidden assets in the period from 2012 to 2018, is presented in Table 5.

In the total capital of Ukrainian enterprises, the share of hidden assets is $33.7 \%$, in agriculture and transport this share is more than half, respectively $70.1 \%$ and $54.4 \%$. In industry and construction, only $16.8 \%$ and $14.3 \%$, this is largely due to the negative values of social capital.

\section{Conclusions}

On the grounds of a methodological approach based on the identification of generic concepts and essential features, a generalized definition of the concept of "hidden assets" is proposed, which covers all the variety of points of view on this phenomenon. Analysis of existing methodological approaches to the assessment of hidden assets has shown that they have significant methodological shortcomings and difficulties in applying and collecting the necessary initial data. Methodological bases for estimation of hidden assets are proposed based on the defined concept of "public value of an enterprise" as the sum of all assets used by an enterprise to create gross value added. Calculations have shown that the average share of hidden assets of Ukrainian enterprises in the period from 2012 to 2018 in the total volume of all assets is $33.7 \%$, and by type of economic activity from $14.3 \%$ in construction to $70.1 \%$ in agriculture. The share of human capital of Ukrainian enterprises in the period from 2012 to 2018 in the total volume of all assets is $26.9 \%$, and by type of economic activity from $18.8 \%$ in trade to $36.6 \%$ in transport. The share of social capital of Ukrainian enterprises in the period from 2012 to 2018 in the total volume of all assets is only $3.5 \%$. In industry and construction, it has negative value (-13.5\% and $-16.4 \%$, respectively).

Table 5

Structure of capital of Ukrainian enterprises by the type of activity,

\begin{tabular}{|c|c|c|c|c|c|c|c|c|c|}
\hline & \multicolumn{5}{|c|}{ Balance sheet (recorded) assets } & \multicolumn{4}{|c|}{ Hidden assets } \\
\hline & Total & FA and $\mathrm{IA}^{*}$ & Reserves & $\mathrm{AR}^{* *}$ & Other & Total & Human capital & Natural capital & Social capital \\
\hline TOTAL & 66.3 & 19.7 & 7.9 & 22.4 & 16.4 & 33.7 & 26.9 & 3.3 & 3.5 \\
\hline Agriculture & 29.9 & 5.8 & 5.7 & 13.6 & 4.8 & 70.1 & 20.3 & 18.5 & 31.3 \\
\hline Industry & 83.2 & 32.6 & 10.4 & 26.7 & 13.5 & 16.8 & 30.3 & 0 & -13.5 \\
\hline Construction & 85.7 & 10.7 & 14.3 & 31.1 & 29.7 & 14.3 & 30.6 & 0 & -16.4 \\
\hline Trade & 66.0 & 4.7 & 12.5 & 34.0 & 14.7 & 34.0 & 18.8 & 0 & 15.2 \\
\hline Transport & 45.6 & 31.4 & 2.0 & 6.8 & 5.4 & 54.4 & 36.6 & 0 & 17.8 \\
\hline
\end{tabular}

taking into account the hidden assets in the period from 2012 to 2018 , as a percentage

* - FA and IA (fixed assets and intangible assets)

** - AR (accounts receivable) 
Hidden assets are the missing link in determining the level of capitalization of an enterprise. All other things being equal, the difference in the level of economic development of enterprises can be explained by differences in the volume and structure of their hidden assets. Hidden assets can be the key to creation of an enterprise's development strategy.

\section{Acknowledgements}

This publication was prepared within the framework of the scientific project "Organizational and economic mechanisms of increasing entrepreneurial activity in Ukraine " at the expense of the budget program "Support of priority areas of scientific research development" (KPKVK 6541230).

\section{References:}

Bryl, L., \& Truskolask, S. (2015). The intellectual capital effectiveness and enterprises' performance-empirical study of Polish listed companies using VAIC method. Managing Intellectual Capital and Innovation for Sustainable and Inclusive Society: Managing Intellectual Capital and Innovation; Proceedings of the MakeLearn and TIIM Joint International Conference 2, ToknowPress.

Burkynskyi, B., \& Horiachuk, V. (2014). Kapitalizatsiia ekonomiky rehioniv Ukrainy [Capitalization of the economy of the regions of Ukraine]. Odesa: IPREED NANU.

Chukhrai, N. (2012). Stratehichne upravlinnia pidpryiemstvom cherez vykorystannia "prykhovanykh aktyviv" [Strategic management of the enterprise through the use of "hidden assets"]. Voctochno-evropeiskiizhurnal peredovylh tekhnologii "Integrirovannoe strategicheskoe upravlenie, upravlenie proektami i programmami", vol. 1/13(55), pp. 8-11. Fijałkowska, J. (2014). Value Added Intellectual Coefficient (VAIC ${ }^{\mathrm{rm}}$ ) as a Tool of Performance Measurement: 15(1), 129-140. Available at: https://content.sciendo.com/view/journals/eam/15/1/article-p129.xml

Fisher, I. (1927). The Nature of Capital and Income. New York, 52.

Forte, W., Matonti, G., Tucker, J. \& Nicolo, G. (2017). MtB versus VAIC in measuring intellectual capital: Empirical evidence from Italian listed companies. 13th Interdisciplinary Workshop on Intangibles and Intellectual Capital Value Creation, Integrated Reporting and Governance, Ancona, Italy, September 21-22, 2017, Università Politecnicadelle Marche, Ancona, Italy, 21-22 September 2017. Università Politecnicadelle Marche, Ancona, Italy: European Institute for Advance Studies in Management. Available at: http: / / eprints.uwe.ac.uk/33500

Golovchanskaia, E., \& Strelchenia, E. (2015). Genezis osnovnykh podkhodov I metodoc otcenki intellektualnykh resursov [Genesis of the main approaches and methods for assessing intellectual resources]. Voprosy innovacionnoj jekonomiki, vol. 5(4), pp. 267-286.

Hayes, A. (2020). QRatio - Tobin's Q. Available at: https://www.investopedia.com/terms/q/qratio.asp INSIDERpro (2017). Skrytye aktivy [Hidden assets]. Available at: https://ru.insider.pro/terms/Skrytye-aktivy/ Javornik, S., Tekavčič, M., \& Marc, M. (2012). The Efficiency of Intellectual Capital Investments as a Potential Leading Indicator International Business. Economics Research Journal, vol. 11(5), pp. 535-558.

Komarova, A., \& Krupina, A. (2017). Intellektualnyi capital kak factor vneshnetorgovoi strategii kompanii [Intellectual capital as a factor in the company's foreign trade strategy]. Rossijskij vneshnejekonomicheskij vestnik, vol. 12, pp. 113-122.

Koritckii, A. (2013). Vliianie chelovecheskogo kapitala na ekonomicheskii rost [The impact of human capital on economic growth]. Novosibirsk: NGASU (Sibstrin).

Lekarkina, N. (2017). Intellektualnyi capital v otcenke intellektualnoi sobstvennosti [Intellectual capital in the valuation of intellectual property]. Otsenka investitcii, vol. 1(5), pp. 35-53.

Li, Z., Chen, Z., Lui, T. T. S., \& Chu, S. K.W. (2016). The impact of Intellectual Capitalon Companies' Performances: A Study Based on MAKE Award Winnersand Non-MAKE Award Winner Companies. International Conference on Knowledge Management, ICKM 2016, Vienna, Austria.

Lopatnikov, L. (Ed.) (2003). Ekonomiko-matematicheskii slovar. Slovar sovremennoi ekonomicheskoi nauki. [Economic and mathematical dictionary: Dictionary of modern economic science]. Moskva: Delo. Available at: http://economic mathematics.academic.ru/4136/\%D0\%A1\%D0\%BA\%D1\%80\%D1\%8B\%D1\%82\%D1\%8B\% D0\%B5_\%D0\%B0\%D0\%BA\%D1\%82\%D0\%B8\%D0\%B2\%D1\%8B

Mohamed, I. (2017). Methods of Measuring Intellectual Capital and the Efficiency of Investment It: Advantages \& Disadvantages. Analytical Comparative Study Imperial Journal of Interdisciplinary Research (IJIR), vol. 3(2), pp. 1083-1092. Available at: https://www.onlinejournal.in/IJIRV3I2/183.pdf

Moiaosvita (2017). Shcho take aktyv: vyznachennia [What is an asset: definition]. Available at: http://moyaosvita.com.ua/finansu/shho-take-aktiv-viznachennya/

Pulic, A. (2008). The Principles of Intellectual Capital Efficiency, a Brief Description. Zagreb. Available at: http://www.cik-hr.com/data/principles_2008.pdf

Piketty, T. (2014). Capital in the Twenty-First Century. Harvard University Press.

Shchepotev, A. (2011). Uluchshenie finansovoi otchetnosti putem vyiavleniia, otcenki i registratcii "skrytykh" i "mnimykh" aktivov i obiazatelstv [Improving financial reporting by identifying, assessing and recording "hidden" and "imaginary" assets and liabilities]. Available at: http://www.kodeks.ru/sovershenstvovanie_finansovoi_ otchetnosti.html 
Smriti, N., \& Das, N. (2017). Impact of intellectual capital on business performance: Evidence from Indian pharmaceutical sector. Polish Journal of Management Studies, vol. 15(1), pp. 232-243.

Sokolianskii, V., \& Sysoeva T. (2015). Sravnitelnyi analiz metodov otcenki stoimosti intellektualnogo kapitala (chast 1) [Comparative analysis of methods for assessing the value of intellectual capital (part 1)]. Voprosy ekonomicheskikh nauk, vol. 4, pp. 107-111.

Stahle, P., Stahle, S., \& Aho, S. (2011). Value added intellectual coefficient (VAIC): a critical analysis. Journal of Intellectual Capital, vol. 12(4), pp. 531-551. doi: https://doi.org/10.1108/14691931111181715

Svanadze, S., \& Kowalewska, M. (2015). The measurement of intellectual capital by VAIC method example of WIG20. Online Journal of Applied Knowledge Management, vol. 3(2), pp. 36-44. Available at: http://www.iiakm.org/ojakm/articles/2015/volume3_2/OJAKM_Volume3_2pp36-44.pdf

Sveiby, K.-E. (2010). Methods for Measuring Intangible Assets. Available at: https://www.sveiby.com/files/ pdf/1537275071_methods-intangibleassets.pdf

Viazemskaia, V. (n.d.). Skrytye aktivy v biznese [Hidden assets in business]. Available at: http://www.markint.ru/ skrytye-aktivy-v-biznese-2/ 